\title{
EFFECT OF FIBER LENGTH VARIATIONS ON MECHANICAL AND PHYSICAL PROPERTIES OF COIR FIBER REINFORCED CEMENT-ALBUMEN COMPOSITE (CFRCC)
}

\author{
A. ZURAIDA, S.NORShAHIDA, I. SOPYAN AND H. ZAHURIN \\ Department of Manufacturing and Materials Engineering, Faculty of Engineering, \\ International Islamic University Malaysia (IIUM), P.O. Box 10, 50728 Kuala Lumpur, \\ Malaysia.
}

E-mails: zuraidaa@iium.edu.my,adihahs_ron@yahoo.com

\begin{abstract}
This paper evaluated the effect of fiber length on the mechanical and physical performance of coir fiber reinforced cement-albumen composites (CFRCC). Albumen protein was added as a binder and the coir fibers with the lengths of 0 (control cement composite), 2.5, 5, 10 and $20 \mathrm{~mm}$ was used as partial replacement of the cement mixture. Flexural and compressive strength, bulk density, moisture content and water absorption were investigated. The experimental investigations revealed that increasing in length of fiber increase the flexural strength. Incorporation of long fiber into the cement paste however, decreased the workability and thus introduced voids which resulted in low density. In fact, the water absorption and moisture content were also increased.
\end{abstract}

ABSTRAK: Kerja ini menilai pengaruh panjang serat terhadap prestasi mekanik dan fizikal serat sabut diperkuatkan komposit simen-albumen (CFRCC). Albumen protein ditambah sebagai bahan pengikat dan serat sabut dengan panjang O(kawalan komposit simen), 2.5, 5, 10 dan $20 \mathrm{~mm}$ telah digunakan sebagai pengganti sebahagian dari campuran simen. Kekuatan lenturan dan mampatan, ketumpatan, kadar kandungan air dan penyerapan air diselidiki. Penyelidikan eksperimental mendedahkan bahawa peningkatan panjang serat meningkatkan kekuatan lentur. Gabungan serat panjang ke dalam adunan simen bagaimanapun,menurunkan kebolehkerjaan dan menghasilkan rongga yang mengakibatkan kepadatan rendah. Bahkan, penyerapan dan kandungan air juga meningkat.

KEYWORDS: Egg albumen, Cement, Coir fiber, Biopolymer, Matrix, Composite 


\section{INTRODUCTION}

The concrete industries in Malaysia have been an active, integrated and growing. Yet, the industry not stuck in the present but keen to seek out new markets, invest in the future and raise productivity and quality. It is generally known that ordinary cement based composites have been long occupied in industry because of it is relatively low price and uncomplicated in processing. Even so, the concern now is therefore lies in creation towards environmental friendly with higher performance type of cement based composite. Faced by these adversaries, cement industry promotes widespread application of best practices and technologies to reduce the amount of limestone calcinations, energy usage and emissions of carbon dioxide. Hence, there should be greater utilization of ingredients, materials and systems that can improve the functionality and durability of cement products without destructing the environment. The search for alternative binder or cement replacement materials led to the discovery of the potential of using agriculture wastes. Amongst the various types of residues from agriculture industry, coconut fiber is the most economical in terms of availability [1]. The use of coir fiber in cementitious material is assumed to be effective toward produce lightweight product. On the other hand, the employment of biopolymer in building material is expected to results in better processability, higher strength and reduction of final material brittleness. It is anticipated egg albumen will toughen and regulate the qualities of cement composite. It is timely that we have developed biopolymer-added cement composite with natural fiber as reinforcement. Hence, the efforts currently is under way in producing lightweight cement composite with use of agriculture waste, coir fiber, and biopolymer, egg albumen in turn to reduce the use of Portland cement which at the same time provide composite with better attributes. Research has shown good prospects in terms of properties which are comparable to ordinary cement based composite.

Asasutjaritet al. [2] claimed that the effect of fiber length is inversely proportional to the mechanical properties. This opinion advocates that the short fiber become mineralized earlier than long fibers. In short fiber-reinforced composite, there are more end points which create facilities for the penetration of cement hydration products. Consequently, the loss of flexibility of the fibers is accelerated. Moreover, the longer the fiber length, the higher the water absorption since the incorporation of long coir fibers into the mix decreased the workability and increased void spaces. According to Li et al. [3], short fibers of coir fiber-reinforced cementitious composite show better flexural strength than the long fibers. This is attributed to the long fiber that is neither well-dispersed nor straightened. As well, Asasutjarit et al. [2] found that the composite samples having fiber lengths of 1-4 cm are likely to yield better mechanical properties.

It is well understood that the fiber length plays an important role in the properties of fiber cement composites. In this present work, focus is placed on the influence of fiber length on mechanical and physical properties of CFRCC. Evidence for fiber length variations on the flexural, compression, density, moisture content and water absorption are presented. 


\section{EXPERIMENTAL PROCEDURES}

\subsection{Materials}

Locally produced Duracem White Portland cement (WPC) was obtained from Duracem Coating Industries Sdn. Bhd., Malaysia. As received cement powders were sieved in order to obtain a granular size below $500 \mu \mathrm{m}$. The body component contained in commercial WPC powders was identified precisely by Fourier Transform Infrared (FTIR) spectrometer (Perkin Elmer FT-IR, Spectrum 100 Series) using ATR method. All spectra were measured in transmittance in the $4000 \mathrm{~cm}^{-1}-380 \mathrm{~cm}^{-1}$ range.

The brown colored and matured coir fiber used in this work was supplied by HK Mega Trading Sdn. Bhd, Malaysia and the coir fibers were untangled to rip the fibers into an individual state. They were sieved to remove shorter fiber and contaminant. Coir fibers were washed with clean tap water for 30 minutes and air-dried in oven at $60^{\circ} \mathrm{C}$ for 8 hours before cut into required test length. The coir fiber was then subjected to FT-IR characterization to identify their chemical constituents. The major bands of coir fiber and their peak assignments to chemical bonds were identified precisely by FTIR spectrometer (Perkin Elmer FT-IR, Spectrum 100 Series) using ATR method. All spectra were measured in transmittance in the $4000 \mathrm{~cm}^{-1}-380 \mathrm{~cm}^{-1}$ range.

Fresh eggs were supplied by FFM Farms Sdn. Bhd., Malaysia. Egg white (albumen) in the liquid form was obtained by first breaking fresh egg and following complete removal of the adhering yolk by using egg separator. Albumen solution was beaten for 3 minutes or until the entire albumen has been converted to froth. The albumen froth was allowed to settle in a covered container for 24 hours. Then, the albumen drained through muslin. After settling for 24 hours and ageing for 1 day, it is a yellowish homogeneous liquid which indicates its readiness for use. Thermal properties of albumen solution which underwent denaturation and aging process were examined using Differential Scanning Calorimetry (DSC) (Perkin Elmer, Sapphire) at $2^{\circ} \mathrm{C} / \mathrm{min}$ in the range $30-120^{\circ} \mathrm{C}$.

\subsection{Composite Fabrication}

In the CFRCC samples preparation, the fiber with the length of $0,2.5,5,10$ and 20 $\mathrm{mm}$ were added to the slurry of albumen and cement, and the ratio of albumen and fibercement was 65:35 (volume percent). They were mixed homogeneously in a laboratory mechanical mixer at a constant speed of $150 \mathrm{rpm}$. The mixture then poured into a mould and compacted by vibration. After moulding, the composites were allowed to settle in covered mould at a room temperature of $20 \pm 2{ }^{\circ} \mathrm{C}$ for 24 hours before demoulding. The samples were dried for another 35 days at ambient temperature of $20-25^{\circ} \mathrm{C}$ and $60 \%$ relative humidity. And finally, the physical and mechanical properties such as flexural and compressive strength, density, moisture content and water absorption were measured.

\subsection{Test Method}

Flexural strengths were measured under three point bend loadings with a span of 60 $\mathrm{mm}$ and at the deflection rate of $5 \mathrm{~mm} / \mathrm{min}$. Flexural testing was conducted using Universal Testing Machine (Instron, model 5582) in accordance with ASTM C78.Density was determined following the procedures described in ASTM C1161. The same specimen were weighted, dried in circulating oven to constant mass at $103 \pm 2{ }^{\circ} \mathrm{C}$ and reweighed. 
While, absorption test required the mass of the specimen to be recorded before and after the specimen immersed in $20^{\circ} \mathrm{C}$ water for $1 \mathrm{hr}$ in a water bath.

\section{RESULTS AND DISCUSSION}

\subsection{Characterization of Raw Materials}

Figure 1 shows the FTIR spectra of as received cement powders. The remarkable absorption peaks of 1409,873 and $712 \mathrm{~cm}^{-1}$ are observed. It is believed that these peaks were attributed to the vibration of carbon oxygen double bond in the carbonate ion. The two most prominent peaks at sharp absorptions of 873 and $712 \mathrm{~cm}^{-1}$ imply the presence of calcium carbonate, $\mathrm{CaCO}_{3}$ as the main element in the cement. The presence of $\mathrm{CaCO}_{3}$ compounds confirmed the existence of chalk, limestone, iron oxide and white clay in the powders.

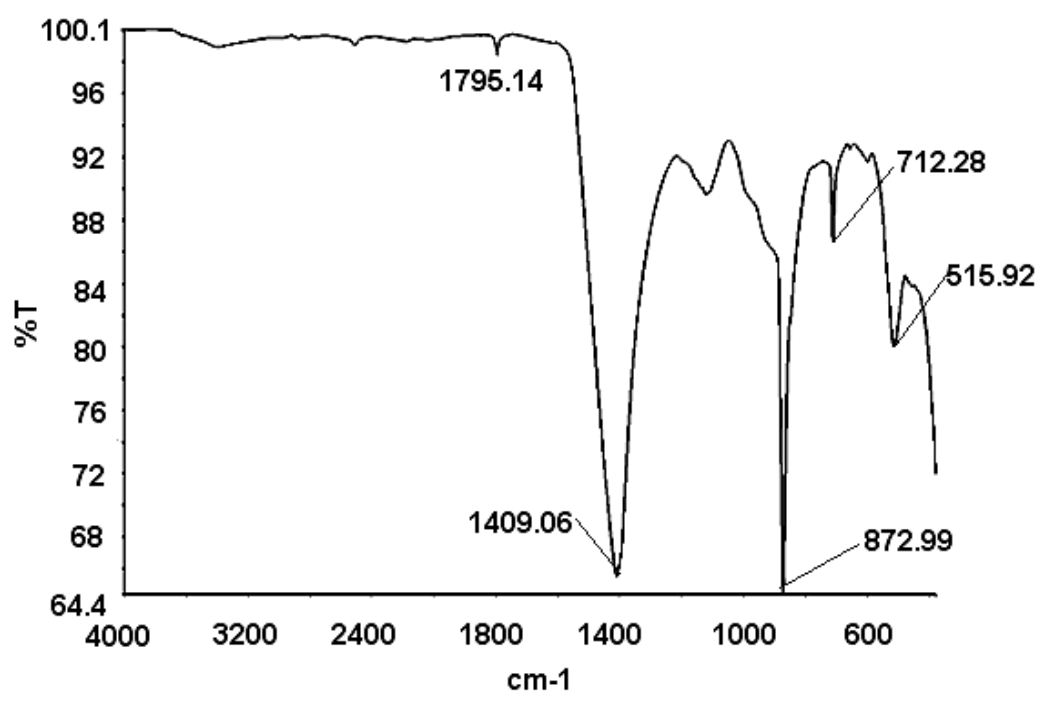

Fig.1:FTIR spectra of cement powder. 


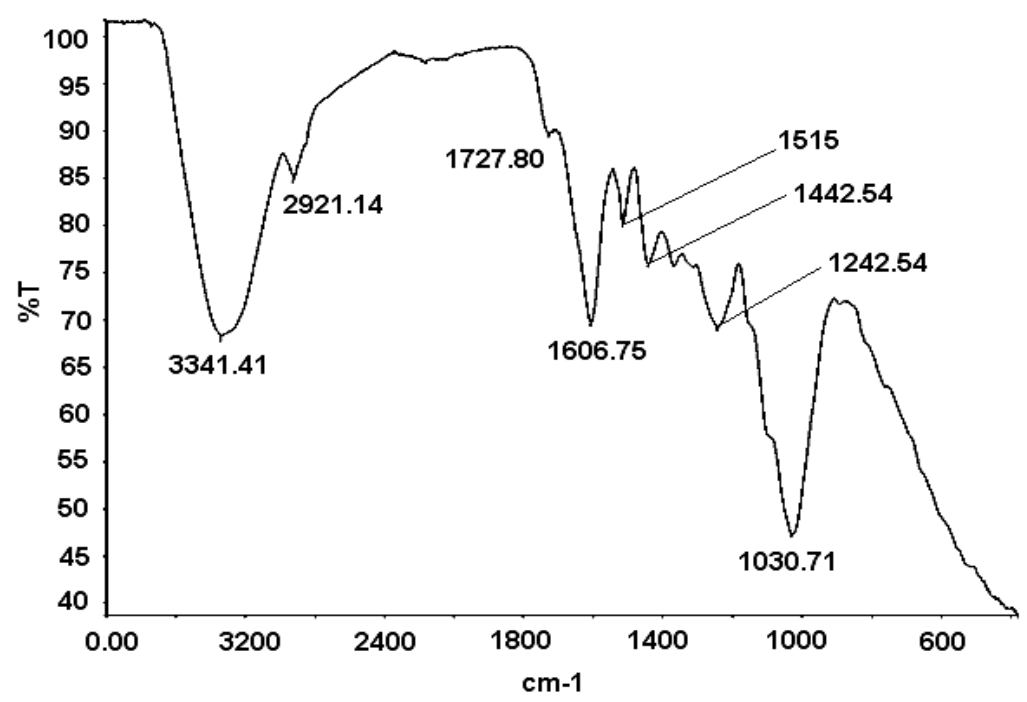

Fig. 2 FTIR spectra of coir fiber.

As seen in Fig. 2, the spectra revealed a strong band at $1030 \mathrm{~cm}^{-1}$ which is due to C-O$\mathrm{C}$ symmetric stretching dialkyl ether linkages and $\mathrm{C}-\mathrm{O}$ stretching vibration in cellulose, hemicellulose and minor lignin contribution. Large band of range between $3600-3100 \mathrm{~cm}^{-1}$ attributed by the polymeric association of the hydroxyl group and the bonded $\mathrm{O}-\mathrm{H}$ stretching vibration exists in carbohydrates (cellulose + hemicellulose) and lignin is observed. Region of absorption involving overlapping bands in the range of 1700-1100 $\mathrm{cm}^{-1}$ are due to $\mathrm{C}-\mathrm{C}, \mathrm{C}=\mathrm{C}, \mathrm{OH}, \mathrm{CO}, \mathrm{CH}_{\mathrm{n}}, \mathrm{C}-\mathrm{O}-\mathrm{C}, \mathrm{CH}$ aromatic linkages and bands at 2921 and $1442 \mathrm{~cm}^{-1}$ are due to vibration of $\mathrm{CH}_{\mathrm{n}}$ (aliphatic and aromatic) which is present in carbohydrates and lignin.

From the DSC traces in Fig. 3, the existence of the endothermic peak determines the denaturation temperature of albumen. There were at least two endothermic peaks observed that attributed to the denaturation of conalbumin, and ovalbumin within the temperature range of $60-100^{\circ} \mathrm{C}$ which confirmed the change occurring upon beating and aging of albumen. 


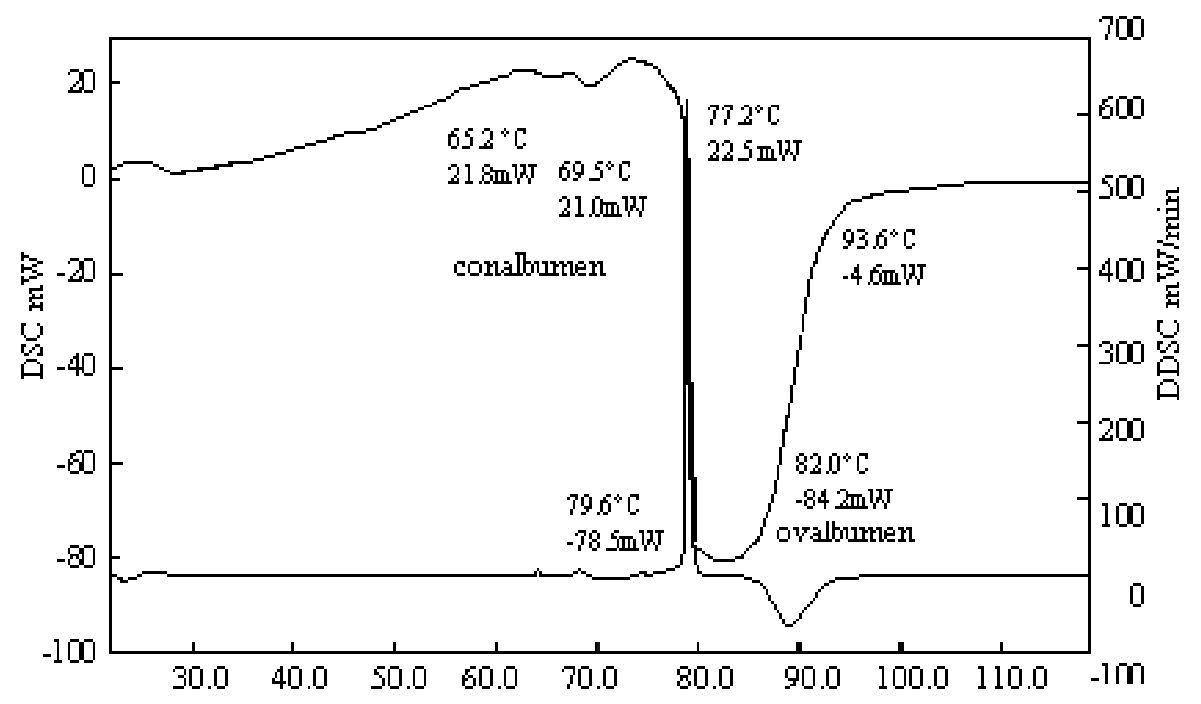

Fig. 3:DSC traces of denatured egg albumen.

\subsection{FTIR Analysis}

The FTIR spectra of coir fiber-reinforced cement-albumen composites are presented in Fig. 4. The spectra indicated a vibration band of $1633 \mathrm{~cm}^{-}{ }^{1}$, which corresponds to the $\mathrm{C}=\mathrm{O}$ stretching band of albumen. The spectra also exhibit the absorption peaks of 1409, 873 and $712 \mathrm{~cm}^{-1}$ which were attributed to the vibrations of carbon oxygen double bond in the carbonate ion of cement powders. The appearance of a strong band at $1030 \mathrm{~cm}^{-1}$ is a vibration in cellulose, hemicellulose and a minor lignin contribution, while the one at 3341 $\mathrm{cm}^{-1}$ corresponded to cellulose. These indicate that each constituent in composite structure was thoroughly reacted and the hydration process was envisaged. 


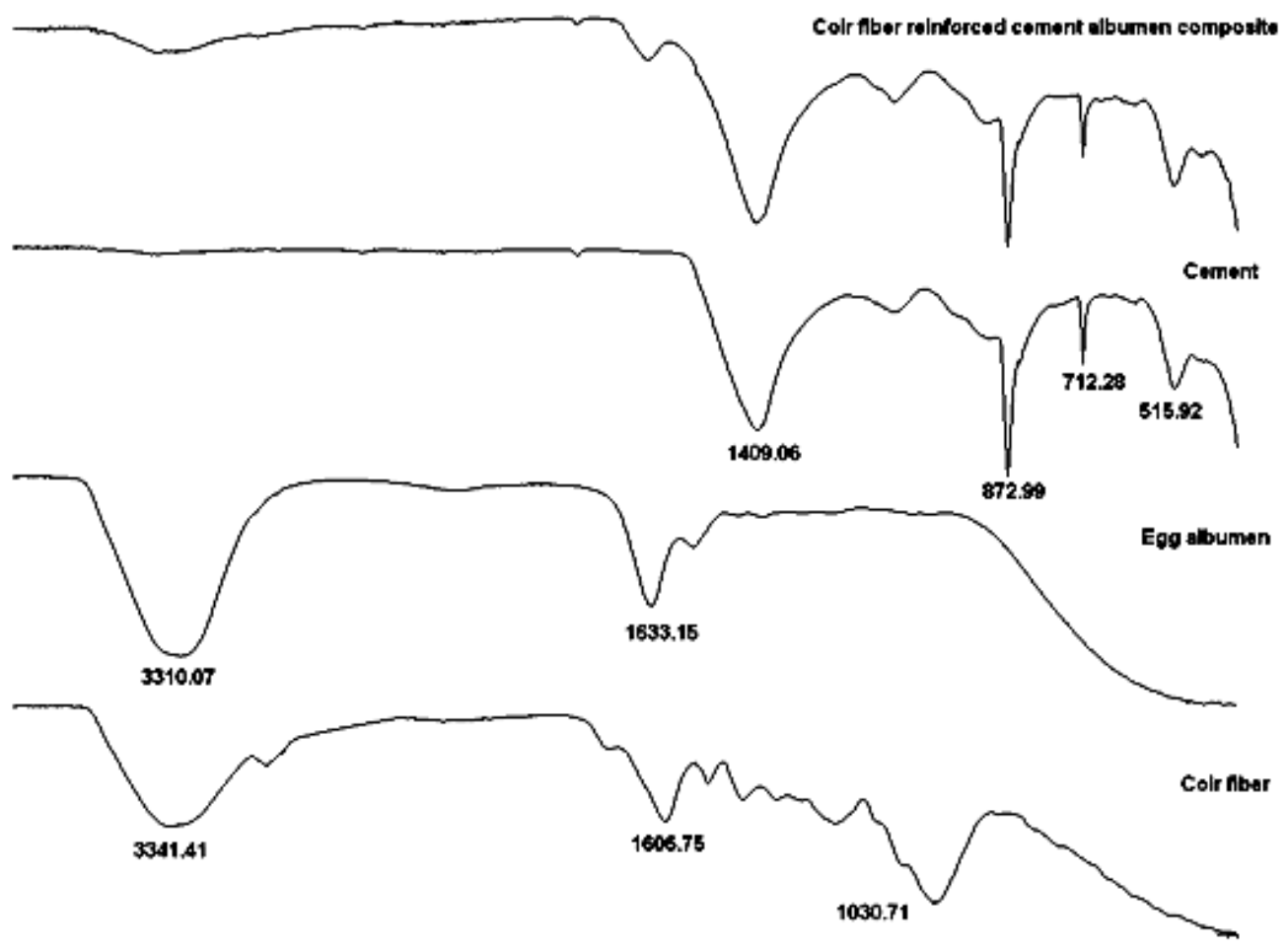

Fig. 4: FTIR spectra of coir fiber reinforced cement-albumen composite.

\subsection{Mechanical Properties}

From Fig. 5, it can be seen that the flexural strength of CFRCC increased with the increase of fiber length with the maximum of $6.719 \mathrm{MPa}$, for fiber length of $5 \mathrm{~mm}$. It is hypothesized that CFRCC with longer fibers are able to bridge cracks more effectively and withstand higher load than CFRCC with shorter fibers. Fiber with length less than $0.3 \mathrm{~mm}$ acts more as filler rather than as reinforcement when used in fiber-reinforced cement composite. Although the amount of fiber loading was sufficient to provide strength, however it results inefficient fiber packing due to its higher volume fractions. Khedari et al. [4] reported that short fibers are more difficult to align and pack densely compared to the long fiber. Another strong reason that contributing to the low strength properties of the CFRCC is too short fibers allow a faster penetration on cement hydration. Consequently the mineralization of the fiber accelerated the loss of flexibility of the fibers. Similar effects have been observed by Asasutjarit et al. [2]. Furthermore, if the fiber is short, then the energy required to pull the fiber through the matrix is low and this can contribute to the dissipation of energy contained in the advancing crack. Therefore, the crack continues through the sample and the material appears to be brittle [5].

The opposite effect, however was observed for composites with fiber length of 10 and $20 \mathrm{~mm}$. Longer fibers tend to ball up resulting in low workability and decline in strength. As can be seen (Fig. 5), the flexural strength decreased to 5.417 and $6.036 \mathrm{MPa}$ for composites reinforced with 10 and $20 \mathrm{~mm}$ fiber lengths respectively. 
Nevertheless, it is postulated that CFRCC specimens attained higher strength compared to cement-albumen composite without coir fiber. The strength is attributed by the presence of fiber, which provides stress transfer during the bending of composite specimen.

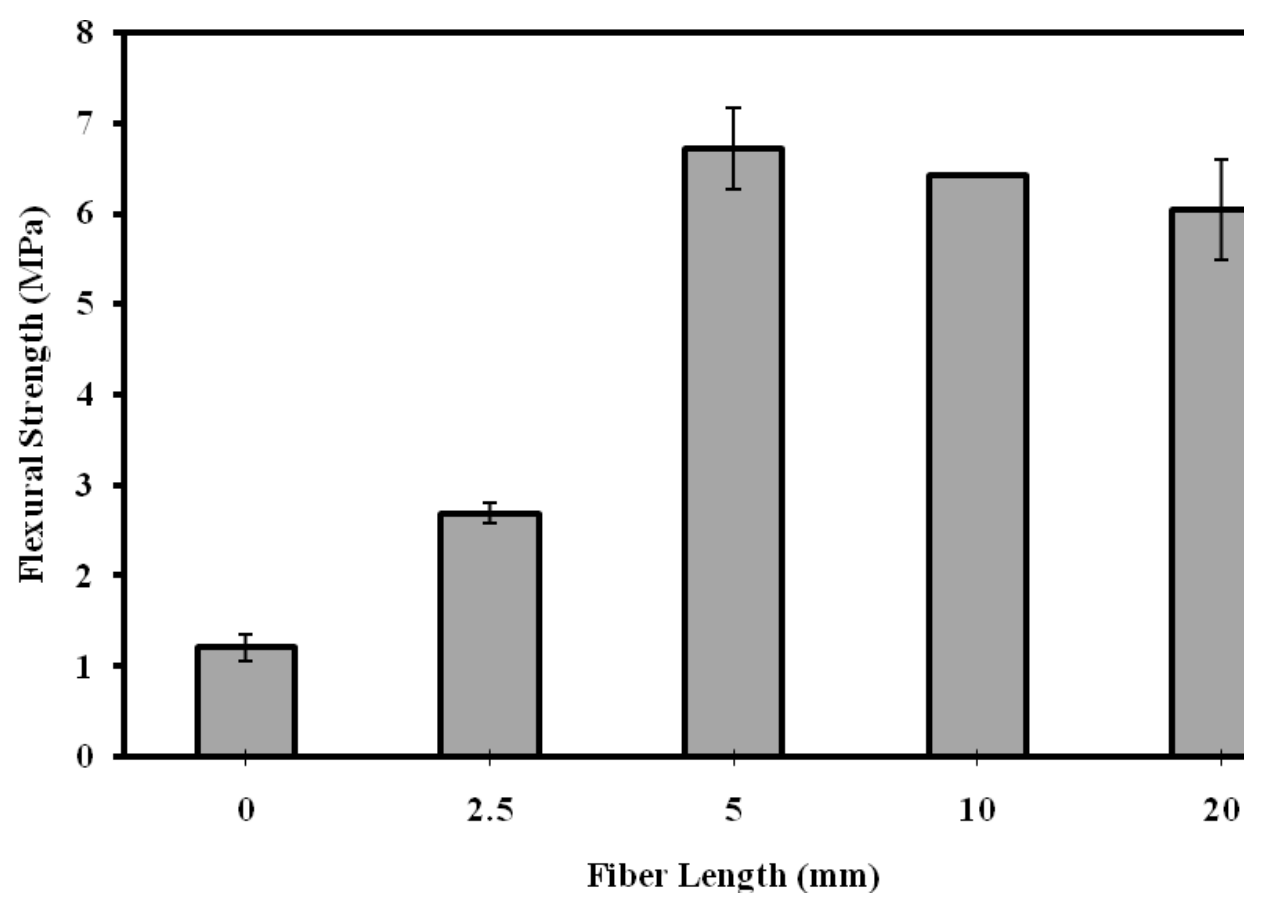

Fig. 5:Flexural strength of CFRCC at different fiber length.

Figure 6 revealed typical failure mode of flexural test specimens. Visual observation showed a macroscopic crack on the composite specimen. It can be seen that specimens with shorter fiber length were split into two pieces and some of the fibers debonded on both sides of the crack. In fact, sudden failure is observed in which the composites appeared to be fail in a brittle manner. This observation is in agreement to the flexural strength obtained in previous findings. For composites specimens reinforced with $5 \mathrm{~mm}$ length fibers, some of the fibers were still linked the two sides of cracks. This proved that the resistance to full separation of composite is provided by the fibers bridging across the cracked surface. This was interpreted as the highest failure forces which contribute to the rise in strength. Nevertheless, composites with longer fibers (in this case, $10 \mathrm{~mm}$ and 20 $\mathrm{mm}$ ) showed multiple cracking which were attributed to a continuous fall of load. At this point, the fibers tend to cluster together and resulting in an inadequate bond and fall in the strength. 


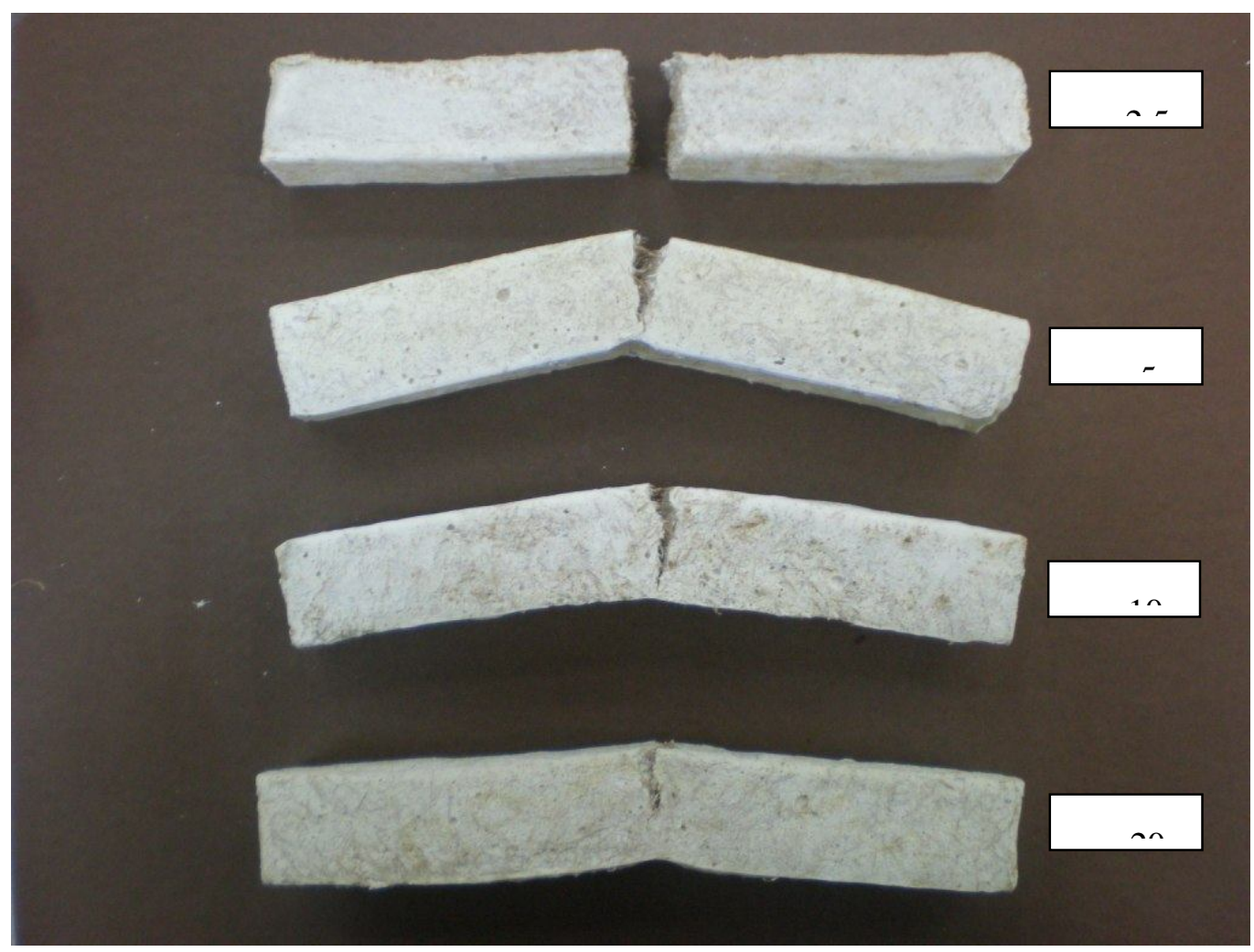

Fig. 6: Photographs showing the fracture modes of CFRCC specimens under flexural stress.

CFRCC samples experienced a drop off in compressive strengths with increasing fiber length as shown in Fig.7. The compressive strength is inversely proportional to the fiber length. Similar findings have been reported by Khedari et al. [4]. It was found that as fiber length increased from 2.5 to $20 \mathrm{~mm}$, the compressive strength dropped from 5.828 to 3.903 MPa. This is related to the fiber spacing in the CFRCC specimen. It is suggested that shorter fibers are aligned to be distant from each other which yield high density and strength. In contrast, longer fibers result in fiber cluster which then creates voids, low density and reduces strength.

On the other hand, the cement-albumen composites exhibited higher compressive strength compared to CFRCC specimens. The mean compressive strength obtained was 16.316 MPa (Fig. 7). A greater amount of cement in the mixture leads to denser product compared to the one reinforced with fiber resulted in higher compressive strength. 


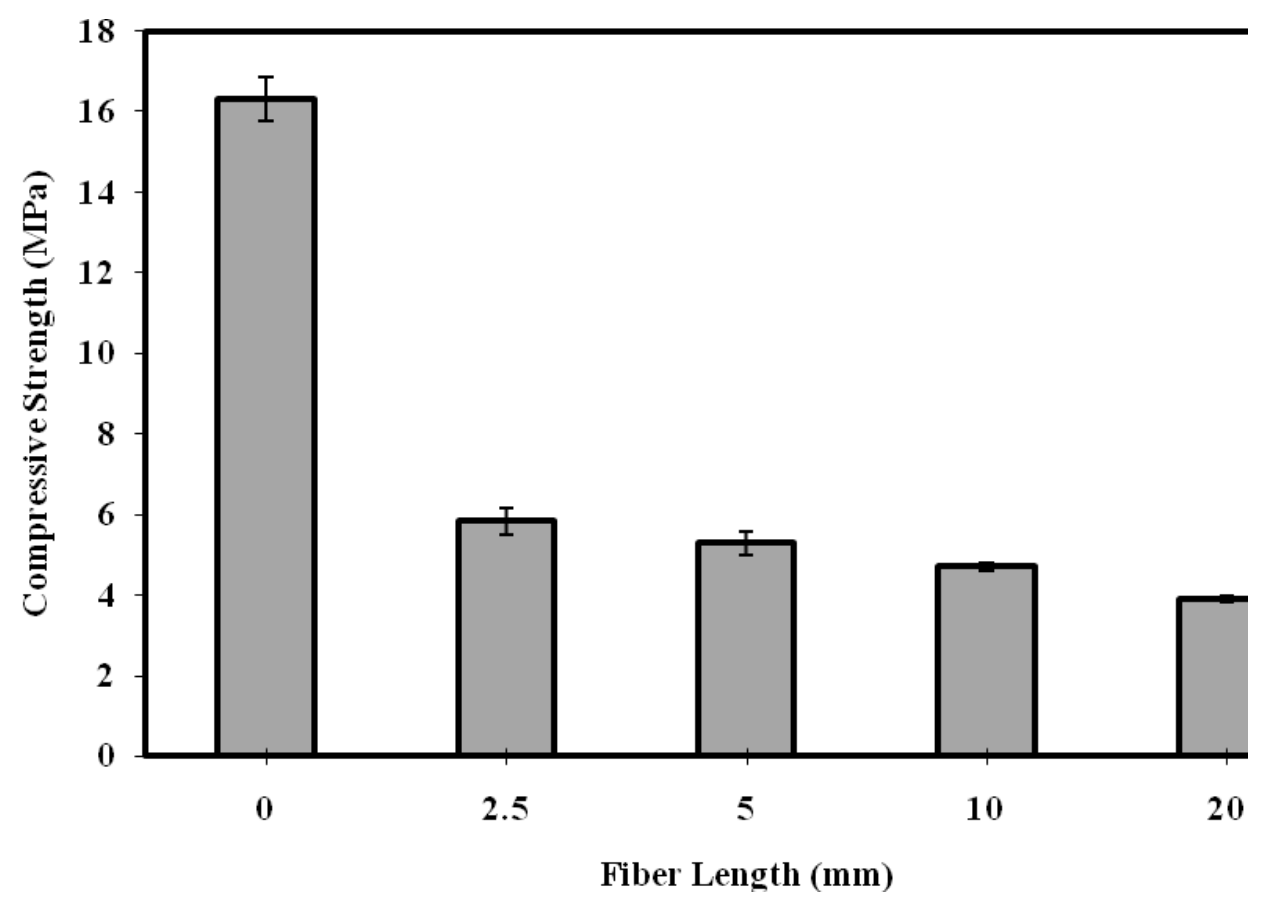

Fig. 7: Compressive strength of CFRCC at different fiber length.

\subsection{Physical Properties}

Figure 8 illustrates the variation in density of composite as the fiber lengths increased in cement composite samples. The results indicate a slight drop off density as fiber length increases. It can be observed that the density decreased from 1.324 to $0.963 \mathrm{~g} / \mathrm{cm}^{3}$ as the embedment length rose from 2.5 to $20 \mathrm{~mm}$. This is due to the fact that the inclusion of long fibers into the composite blend decreased the packing, which lead to the disruption of fiber distribution and resulting in high void spaces. Apparently, greater void contents yield low density composite. As mentioned by Khedari et al. [4], short fibers are aligned and pack densely than the longer ones. On the other, cement-albumen composite obtained a maximum density of $1.257 \mathrm{~g} / \mathrm{cm}^{3}$. This suggested that the inclusion of fibers into plain cement composite had little effect on the density. The density might be reduced slightly compared to cement-albumen composite.

The effect of fiber lengths on moisture content properties of composite is depicted in Fig. 9. For the fiber length in the range of 2.5 to $20 \mathrm{~mm}$, the moisture content increased from 2.572 to $7.482 \%$. This relationship depended on voids volume present in the composite, which would account for the dominant effect on density, moisture content and water absorption. As mentioned previously, inclusion of long fibers into the composite might lead to the disruption of fiber distribution resulting in void spaces. On the basis of these results, specimens with low density have more void spaces which absorb more water and thus resulting in higher moisture content. While, it seems that the cement-albumen 
composite specimens exhibited the least percentage of moisture content. Cement composite that contained natural fibers generally seems to possess a high percentage of moisture content due to its hydrophilic nature.

The effect of fiber lengths on water absorption properties of composite is depicted in Fig. 10. Longer fibers tend to increase the percentage of water absorption. The rate of water absorption increased from 3.024 to $16.021 \%$ for 2.5 to $20 \mathrm{~mm}$ range of fiber lengths. As explained before, the rate of water absorption is greatly affected by the specimen's density and void volumes. Asasutjarit et al. [2] identified that the incorporation of long coir fibers into the mix decreased workability and increased the void space. Consequently, the longer the fiber, the higher is the water absorption. This is in agreement with the findings by $\mathrm{Li}$ et al. [6]. However, for cement-albumen specimens, the percentage of water absorption obtained was $29.778 \%$. It is expected that without the presence of hydrophilic natural fibers, the percentage of water absorption should be lesser. Over mixing might also results in foaming and subsequently resulted in occurrences of pores inside the specimen which was attributed by the entrapped air. Therefore, more water was absorbed from surrounding.

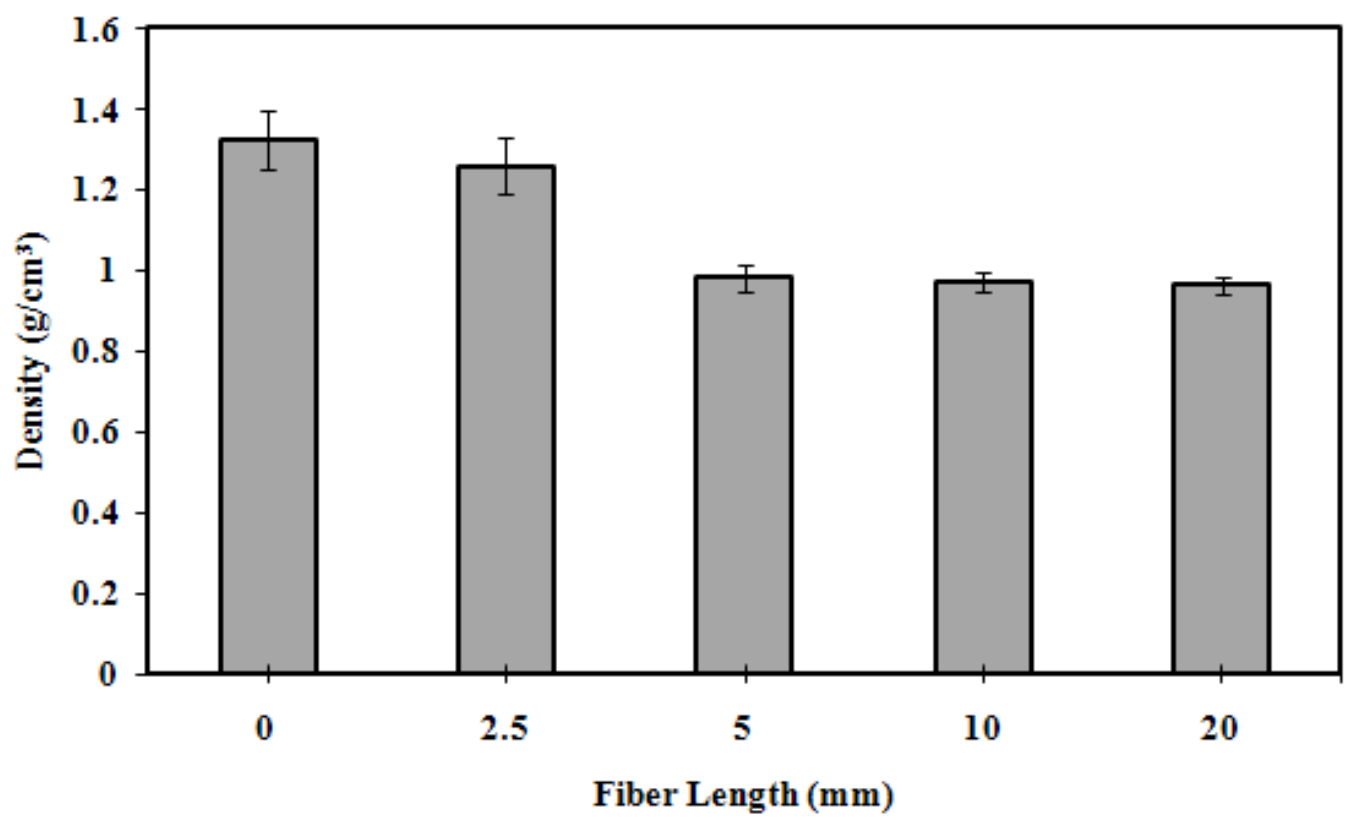

Fig. 8: Density of CFRCC at different fiber length. 


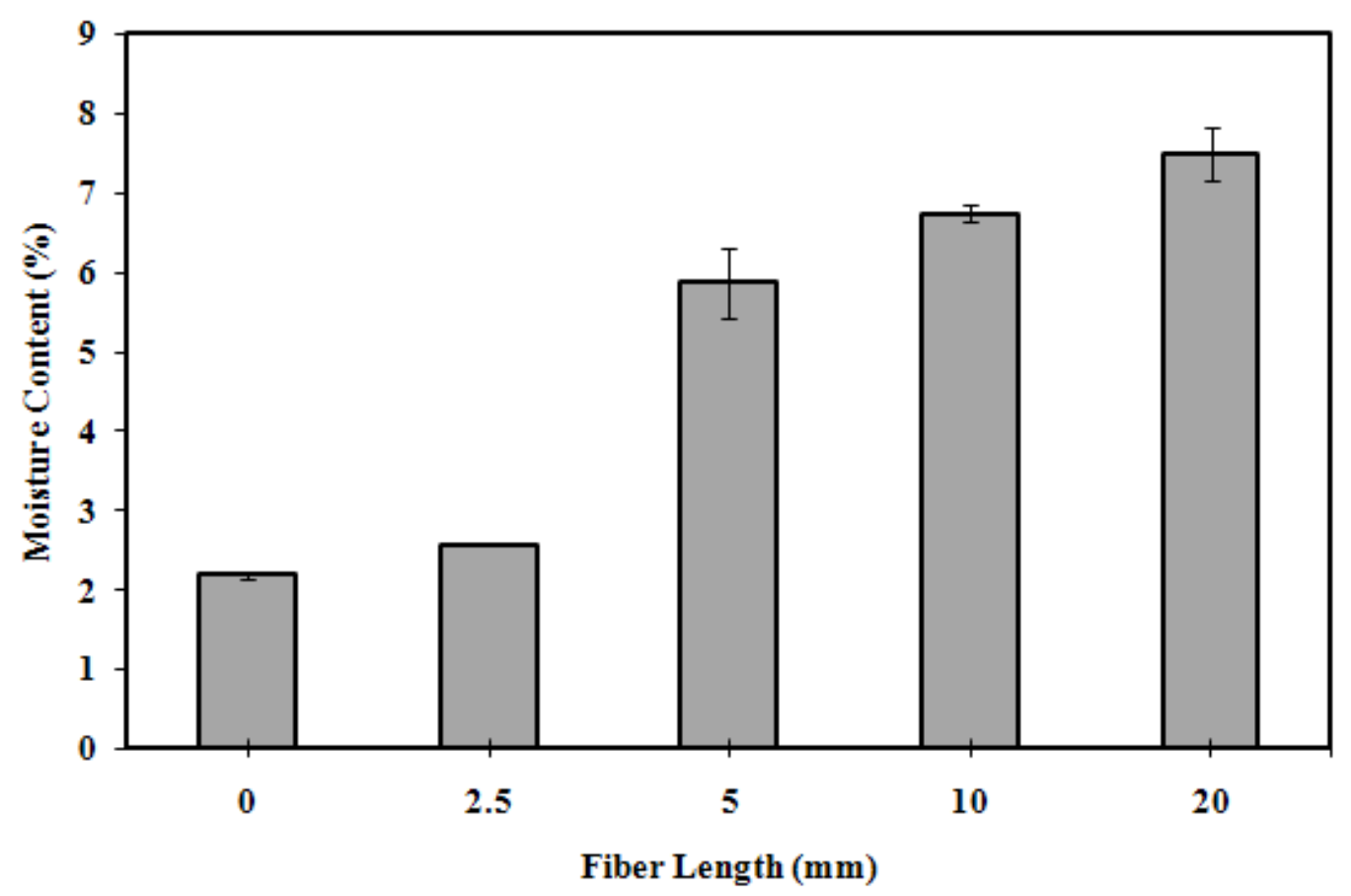

Fig. 9:Moisture content of CFRCC at different fiber lengths.

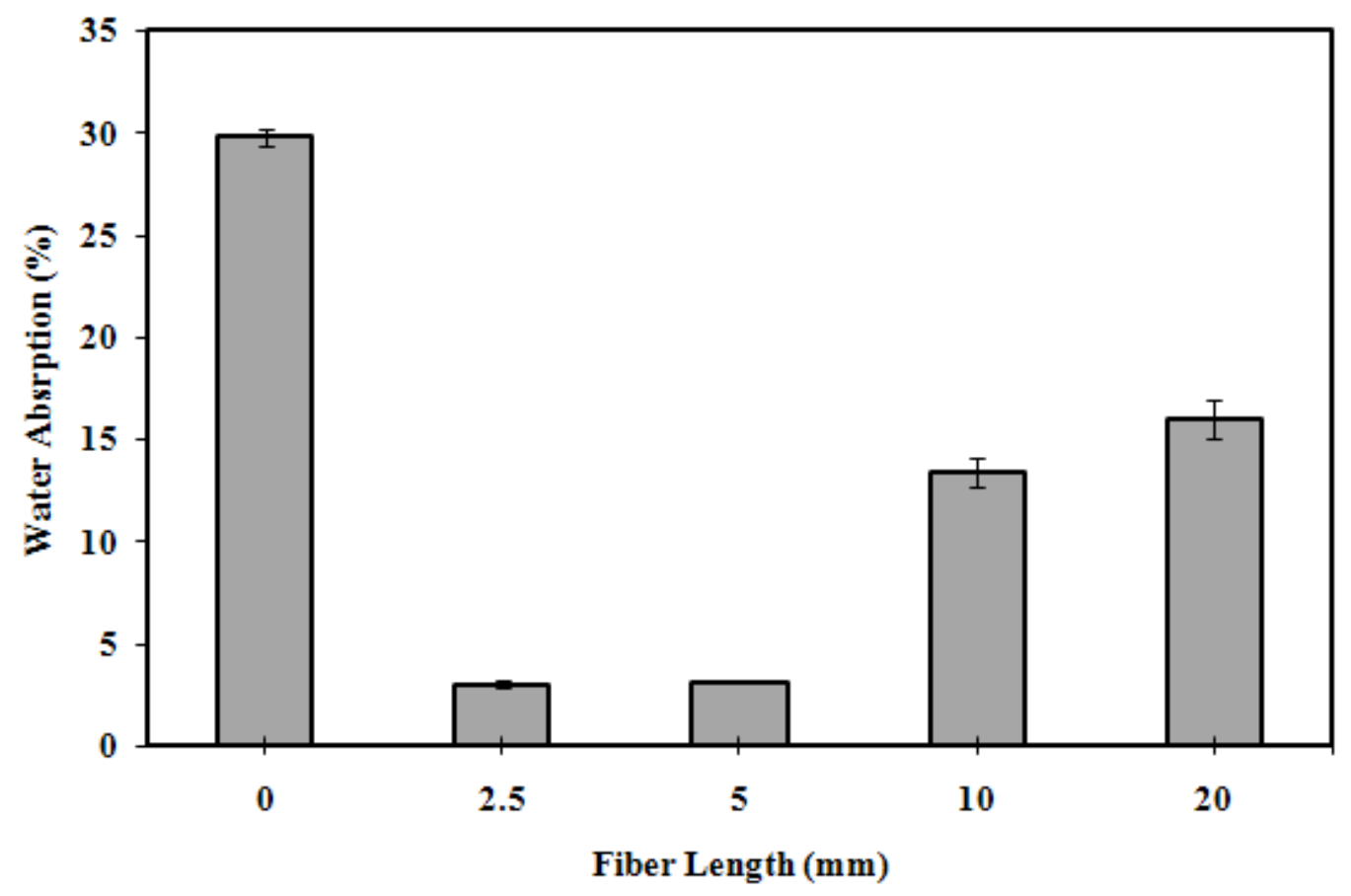

Fig. 10: Water absorption of CFRCCat different fiber lengths. 


\subsection{CONCLUSIONS}

A method for fabricating coir fiber reinforced cement albumen based composite were optimized. Fiber length is one of the significant factors that affects the flexural strength, compressive strength, density, moisture content and water absorption properties of CFRCC. Under conditions reported in this paper, longer fiber is found to be effective in increasing flexural strength. However, it diminished the compressive strength. Inversely, the addition of shorter fiber into the matrix significantly reduces water density, moisture content and water absorption. It can be concluded that, for a given fiber type, length, orientation and volume concentration, the strength of composite was influenced by the bonding between all constituents resulted from distribution of the fiber in the cementalbumen paste.

\section{ACKNOWLEDGEMENTS}

The authors would like to thank the Ministry of Science, Technology and Innovation (MOSTI) for the eScience Research Fund (Grant No. 03-01-08-SF0039), SIRIM Bhd. for their technical help, technicians of Faculty of Engineering, IIUM and the Research Management Centre (RMC) for their much commitment and assistance throughout this research.

\section{REFERENCES}

[1] Romildo, D., Filho, T., Ghavami, K., England, G. L., \& Scrivener, K., "Development of vegetable fibre-mortar composites of improved durability", Cement and Concrete Composite, 25, 185-196, (2003).

[2] Asasutjarit, C., Hirunlabh, J., Khedari, J., Charoencai, S., Zeghmati, B., and Cheul Shin, U., "Development of Coconut Coir Based Lightweight Cement Board", J. of Construction and Building Materials, 21: 277-288, 2007.

[3] Li, Z., Wang, L., \& Wang, X. A. "Cement composites reinforced with surface modified coir fiber", J. of Composite Materials, 41, 1445-1456, 2006.

[4] Khedari, J, Suttidonk, B., Pratinhong, N. \&Hirunlabh, J. "New Lightweight Composite Construction Materials with Low Thermal Conductivity", Cement \& Concrete Composite, 23, 65-70, 2001.

[5] Lindhagen, J.E. and Berglund, L.A. "Application of Bridging Law Concepts to ShortFiber Composites Part 1: DCB Test Procedures for Bridging Law and Fracture Energy", Composite Science \& Technology, 6, 871-883, 2000.

[6] Li, Y. Mai, Y.W. and Ye, L., "Sisal Fiber and Its Composites: A Review of Recent Developments", Composite Science \& Technology, 11, 2037-2055, 2000. 